\title{
SAME-SEX MARRIAGE AND RELIGIOUS EXEMPTION UNDER THE MARRIAGE ACT: WHERE DOES SECTION 29 LEAVE RELIGIOUS OBJECTORS?
}

\author{
Simon Matthew Wilson*
}

\begin{abstract}
This article examines the Marriage (Definition of Marriage) Amendment Act 2013, which amends the Marriage Act 1955 to allow same-sex couples to marry. In particular, it examines the legal position of celebrants who wish to refuse to solemnise same-sex marriages on religious grounds, and attempts to reconcile these celebrants' religious freedoms with the rights of same-sex couples not to be discriminated against based on their sex and/or sexual orientation. While s 29(2) of the Marriage Act now contains a specific exemption for some classes of celebrants, the scope of this exemption is narrow, and not all celebrants are included. This article therefore examines the meaning of s 29(1) of the Marriage Act, and addresses the controversial issue of whether s 29(1) provides a broad exemption for all celebrants. This article asserts that s 29(1) does provide such an exemption, and accordingly all celebrants are able to refuse to solemnise same-sex marriages on religious grounds, despite the limitations in the s 29(2) exemption.
\end{abstract}

\section{INTRODUCTION}

The Marriage (Definition of Marriage) Amendment Act 2013 (MDMAA) was passed on 17 April 2013. The MDMAA amends the Marriage Act 1955 to "clarify that a marriage is between 2 people regardless of their sex, sexual orientation, or gender identity". ${ }^{1}$ It therefore makes same-sex marriage legal in New Zealand. While purporting to clarify the definition of marriage, the MDMAA effectively alters what was until now the common law position reflected in Quilter $v$ Attorney

\footnotetext{
* Article submitted as part of the LLB(Hons) programme at Victoria University of Wellington. I would like to thank my supervisor, Professor Claudia Geiringer, for her guidance. I would also like to thank Ian Wilson and Angi Zanderigo for their constant support and encouragement.

1 Marriage (Definition of Marriage) Amendment Act 2013, s 4.
} 
General (Quilter) that "marriage" is between two people of the opposite sex. ${ }^{2}$ New Zealand was the thirteenth country to allow same-sex marriage nationwide. ${ }^{3}$

Aside from the obvious moral issue surrounding whether a same-sex couple should be able to marry, concern arose as to whether marriage celebrants could lawfully refuse to solemnise same-sex marriages if solemnising them would contravene their religious or moral beliefs. Section 29(1) of the Marriage Act states that "[a] marriage licence shall authorise but not oblige any marriage celebrant to solemnise the marriage to which it relates." Prima facie, it seems that this provision allows celebrants to refuse to solemnise any marriage for whatever reason. However, s 29(1) cannot be viewed in isolation. Celebrants may be subject to human rights obligations from elsewhere in the law, rendering them unable to refuse to solemnise a marriage if to do so would constitute unlawful discrimination (for example on the grounds of sex or sexual orientation). ${ }^{4}$

At the heart of this issue lie two sets of conflicting rights. On one hand, same-sex couples have the right not to be discriminated against based on their sex and/or sexual orientation. ${ }^{5}$ However, celebrants' religious freedoms, both to hold and to manifest religious beliefs, must also be protected. Both parties' rights are guaranteed in domestic and international law. ${ }^{6}$ How, then, can these rights be reconciled? Some take the view that: ${ }^{7}$

To say that one supports same-sex marriage, but not a right to marry that is equal to the right straight people enjoy, because it is riddled with exceptions and segregated so as not to offend traditionalist sensibilities, is a support that exists in theory only.

If the purpose of the MDMAA is to give same-sex couples equal marriage rights, is allowing those with objections to same-sex marriage to refuse to perform such marriages preventing the final step to equality? Conversely, is it arguable that religious freedoms are sufficiently important to justify sanctioning differential treatment in this context? Could achieving absolute equality for same-sex couples at the expense of religious freedoms place a disproportionate burden on celebrants?

2 Quilter v Attorney-General [1998] 1 NZLR 523 (CA) at 526.

3 Max Harris "Marriage Equality in New Zealand - Part I: Religious Exemptions" (2013) Oxford Human Rights Hub <www.ohrh.law.ox.ac.uk>.

4 See New Zealand Bill of Rights Act 1990, s 19; Human Rights Act 1993, s 21(a) and (m).

5 Please note that this article will refer to the rights of "couples", rather than "the individuals within couples" for the sake of simplicity.

6 New Zealand Bill of Rights Act 1990, ss 13, 15 and 19; Human Rights Act 1993, ss 44, 21 and 65; International Covenant on Civil and Political Rights 999 UNTS 171 (adopted 16 December 1966, entered into force 23 March 1976), arts 18 and 26.

7 Shannon Gilreath "Not a Moral Issue: Same-Sex Marriage and Religious Liberty" (2010) U Ill L Rev 205 at 212-213. 
The legislature's response was to insert s 6 into the MDMAA (later becoming s 29(2) of the Marriage Act), amending the Marriage Act to expressly allow some celebrants a religious exemption. Section 29(2) states:

Without limiting the generality of subsection (1), no celebrant who is a minister of religion recognised by a religious body enumerated in Schedule 1, and no celebrant who is a person nominated to solemnise marriages by an approved organisation, is obliged to solemnise a marriage if solemnising that marriage would contravene the religious beliefs of the religious body or the religious beliefs or philosophical or humanitarian convictions of the approved organisation.

The scope of the exemption in s 29(2) is limited however: it does not allow refusal based on the views of the individual celebrant (for example if he or she objects to same-sex marriage even though his or her church or organisation does not), nor does it include all types of celebrants. As a result, a large proportion of celebrants are not covered by the exemption. These celebrants can therefore only lawfully refuse to solemnise a marriage if s 29(1) permits it, and it is thus crucial to know the extent of the protection afforded by this provision, and whether it can be relied on by religious objectors. This article therefore focuses on whether s 29(1) of the Marriage Act (without s 29(2)) allows celebrants to lawfully refuse to solemnise same-sex marriages if solemnising such marriages would contravene those celebrants' religious beliefs.

This article will show that celebrants exercise a public function when solemnising marriages, and the New Zealand Bill of Rights Act 1990 (NZBORA) therefore applies to their actions. It will then conclude that on its proper construction s 29(1) does not override obligations arising from NZBORA. A celebrant may therefore only rely on s 29(1) and refuse to solemnise a marriage if to do so would not contravene NZBORA. Finally, it will conclude that a refusal on religious grounds would be a justifiable limit on a couple's right to freedom from discrimination, and thus lawful under NZBORA. Section 29(1) therefore allows any celebrant to refuse to solemnise a marriage based a legitimate religious objection. This article will also explore an alternative scenario in which s 29(1) is found, on its proper construction, to exclude rights arising from NZBORA, and determine whether the courts would accept such a meaning in light of $s$ of NZBORA.

\section{THE STATUTORY SCHEME}

All couples wishing to get married must receive a marriage licence from a registrar, ${ }^{8}$ and have their marriage solemnised by either a registrar or a marriage celebrant. ${ }^{9}$ There are three types of celebrant set out in the Marriage Act.

The first type consists of ministers of religion (ministers) representing any of the ten religious bodies enumerated in sch 1 of the Act. ${ }^{10}$ The second class consists of celebrants nominated by

8 Marriage Act 1955, ss 30(1) and 24.

9 Marriage Act 1955, ss 33(1) and 29(1). 
approved organisations (organisational celebrants). ${ }^{11}$ The Registrar-General may allow certain organisations to nominate members to be marriage celebrants if he or she is convinced that at least one of the principal objects of the organisation is to "uphold or promote religious beliefs or philosophical or humanitarian convictions". ${ }^{12}$ There are currently nearly 1,000 approved organisations. ${ }^{13}$ Thirdly, the Registrar-General may appoint an "independent celebrant", ${ }^{14}$ if the person is of an appropriate character and it is in the general public interest, or that of a particular community (defined by geography, interest, belief or another factor) that this person becomes a celebrant. ${ }^{15}$ Independent celebrants are excluded from s 29(2), and may only refuse if s 29(1) allows this. ${ }^{16}$ While the issue of whether registrars should be able to lawfully refuse to solemnise marriages is worthy of consideration, registrars are not mentioned in s 29(1), and fall outside the scope of this article.

\section{COULD A CELEBRANT LAWFULLY REFUSE TO SOLEMNISE A SAME-SEX MARRIAGE ON RELIGIOUS GROUNDS UNDER S 29(1)?}

To recapitulate, s 29(1) states that "[a] marriage licence shall authorise but not oblige any marriage celebrant to solemnise the marriage to which it relates." ${ }^{17}$ As mentioned above, this provision appears to give celebrants discretion to refuse to solemnise any marriage for any reason. However, celebrants are also subject to obligations from elsewhere in the law, including human rights obligations from the Human Rights Act 1993 (HRA) and NZBORA prohibiting unlawful discrimination. These may make a refusal to solemnise a same-sex marriage unlawful. It must therefore be ascertained:

(1) which human rights obligations apply to celebrants when solemnising marriages;

(2) whether s 29(1) excludes these obligations; and

(3) whether, if these obligations are not excluded by s 29(1), it is nevertheless lawful for a celebrant to refuse to solemnise a marriage based on religious grounds.

10 Marriage Act 1955, s 8 and sch 1.

11 Organisations are approved under the Marriage Act 1955, s 10.

12 Marriage Act 1955, s 9(4).

13 Department of Internal Affairs "List of Churches and Approved Organisations" < www.dia.govt.nz>.

14 Marriage Act 1955, s 11.

15 Marriage Act 1955, s 11(3).

16 Marriage (Definition of Marriage) Amendment Act 2013, s 6.

17 Marriage Act 1955, s 29(1). 


\section{A Which Human Rights Obligations Apply?}

Different human rights obligations apply in respect of discrimination, depending on whether NZBORA applies to the person or body in question. Part 2 of the HRA deals with discrimination by persons or bodies whose actions are not subject to NZBORA. ${ }^{18}$ A person (or body) to whom pt 2 applies must not do or refuse to do certain actions based on the prohibited grounds of discrimination enumerated in s 21(1) of the HRA. ${ }^{19}$ If NZBORA does apply to the person or body, their actions must not constitute an unjustifiable breach of s 19 of NZBORA. ${ }^{20}$ In order to ascertain which human rights obligations apply to celebrants when solemnising marriages, one must therefore determine whether they fall under s 3 (the application provision) of NZBORA.

Celebrants are not part of the judiciary, legislature or the executive, and are therefore not covered by s 3(a). Section 3(b) states that the NZBORA applies to acts done "[b]y any person or body in the performance of any public function, power, or duty conferred or imposed on that person or body by or pursuant to law." ${ }^{21}$ Celebrants are given the authority to solemnise marriages by the Marriage Act, and therefore exercise powers and functions conferred by law. The trickier issue is whether these functions and powers are public.

\section{Is a celebrant's role of solemnising marriages a public function, power or duty?}

Complicating this issue is the fact that when solemnising most marriages, celebrants can be said to be performing two separate functions: a statutory or legal function and a ceremonial function. This is especially the case with religious marriages, where marriage is viewed as a sacrament, derived from an authority that is divine, rather than statutory. It may therefore be tempting to separate the two functions and analyse only the legal element of solemnisation. However, given that most celebrants and couples see the solemnisation of marriage as more than merely fulfilling a statutory requirement, this distinction would be artificial. The legal solemnisation of a marriage, and the accompanying ceremony and spiritual union, are one in the same, and cannot realistically be separated into component parts. This article therefore asserts that when solemnising marriages, celebrants do not perform two separate functions. Instead, they perform their statutory function under the Marriage Act, but the way in which this is done and the significance attached to it may change according to the couple's beliefs and circumstances.

18 Human Rights Act 1993, s 21A; Paul Rishworth and others The New Zealand Bill of Rights (Oxford University Press, Melbourne, 2003) at 19.

19 See for example Human Rights Act 1993, ss 21(1) and 44.

20 Section 20L; New Zealand Bill of Rights Act 1990, ss 19 and 5.

21 New Zealand Bill of Rights Act 1990, s 3(b). 
The most comprehensive explanation of the scope of $s$ 3(b) is the High Court decision in Ransfield v Radio Network Ltd. Randerson J set out several statements of law and a list of "nonexclusive indicia" for determining whether a function, power or duty is public. ${ }^{22}$ Importantly, while the nature of the entity or person may be a factor, the main focus is on the nature of the function. ${ }^{23}$ A public function may therefore be performed by a private body. ${ }^{24}$ Randerson J's main concern was whether the function is of a "governmental" or essentially private nature. ${ }^{25}$ He stressed that this exercise is fact-dependent, and that it requires a "flexible and generous approach". ${ }^{26}$

It may be argued that the solemnisation of marriages is not a public function. First, celebrants are not employed by the state, nor are religious bodies or approved organisations publicly owned or funded. ${ }^{27}$ Also, celebrants do not exercise coercive or monopolistic powers, and are not democratically accountable for their actions. ${ }^{28}$

The decision of the Court of Appeal in Alexander v Police (Alexander) also suggests that the scope of s 3(b) is narrow. In Alexander, the Court found that the Wellington Free Ambulance (WFA) did not come under s 3(b), despite playing an important public role and receiving public funding. ${ }^{29}$ The WFA also undoubtedly acts in the "broader public interest". ${ }^{30}$ Regardless, these factors were insufficient to bring it within the scope of s 3(b).

However, Randerson $\mathrm{J}$ stressed that the main focus of this inquiry is on the nature of the function, not the body performing it. ${ }^{31}$ The Court in Alexander based its decision on the nature of the body, particularly the fact that the WFA was an independent organisation not under government control, which did not implement a Government policy or programme. ${ }^{32}$ This decision has been criticised by academics for placing too much emphasis on the identity of the provider rather than the nature of the function, ${ }^{33}$ and by Randerson $\mathrm{J}$ for relying on Canadian authorities inapplicable in the

22 Ransfield $v$ The Radio Network Ltd [2005] 1 NZLR 233 (HC) [Ransfield] at [69].

23 At [69].

24 At [69].

25 At [69].

26 At [70].

27 At [69].

28 At [69].

29 Alexander v Police (1998) 4 HRNZ 632 (CA) [Alexander] at 637.

30 As required in Ransfield, above n 22, at [69].

31 At [69].

32 Alexander, above n 29, at 637.

33 Andrew Butler "Is this a Public Law Case?" (2000) 31 VUWLR 747 at 770. 
New Zealand context. ${ }^{34}$ It is therefore likely that the reasoning in Alexander was erroneous. The nature of the function in question, rather than that of the entity, is the real focus. This view is echoed in subsequent case law. ${ }^{35}$

Despite the above arguments, the more persuasive argument is that celebrants do perform a public function and therefore come under s 3(b). Firstly, the source of their function is statutory. ${ }^{36}$ Celebrants are appointed under the Marriage Act, ${ }^{37}$ and their power to solemnise marriages is also given and defined under this Act. ${ }^{38}$ There is also significant governmental control over the solemnisation of marriages. ${ }^{39}$ Section 30 of the Marriage Act sets out the preconditions for solemnising a marriage, including the issuance of a marriage licence under s 24. Solemnisation is essentially the second half of a two-part process to effect a marriage. Furthermore, s 31 imposes requirements regarding the place and form of the solemnisation, including some words to be spoken by the couple. However, statutory control over solemnisation should not be overstated. Section 31(3) only dictates a few mandatory words, and s 31(2) allows the couple to be married "according to such form and ceremony as they may think fit to adopt". Nevertheless, celebrants perform a statutory function regulated by the state.

The statutory function of a celebrant is practically identical to that of a registrar, who is part of the executive. A celebrant can therefore be seen as "standing in the shoes of government" in the exercise of his or her function. ${ }^{40}$ Moreover, getting married inevitably affects the "rights, powers, privileges, immunities, duties and liabilities" of both individuals. ${ }^{41}$ Along with the issuance of a marriage licence, solemnisation is required to form a marriage. The function of solemnisation therefore affects the rights, powers, privileges, immunities, duties and liabilities of the couple. Furthermore, the ability to get married is highly important in society, as evidenced by the desire for universal marriage and the longevity of marriage as an institution. Solemnising marriages is therefore not merely a public benefit, but something that is in the "broader public interest". ${ }^{42}$

34 Ransfield, above n 22, at [57]-[58].

35 See for example Butler v Shepherd HC Auckland CIV-2011-404-923, 18 August 2011 at [58]-[59].

36 Ransfield, above n 22, at [69].

37 Marriage Act 1955, ss 8, 10 and 11.

38 Marriage Act 1955, ss 30 and 31.

39 Legal opinion from Ian Bassett QC (Barrister) for Family First NZ regarding the Marriage Act Amendment Bill (29 August 2012) [Bassett Opinion] at 1-2.

40 Ransfield, above n 22, at [69].

41 At [69].

42 At [69]. 
Finally, characterising solemnisation as a public function accords with the United Kingdom approach. The House of Lords decision in Aston Cantlow PCC $v$ Wallbank ${ }^{43}$ mentions the issue in the context of s 6(3) of the Human Rights Act 1998 (UK), which is similar to s 3(b) of NZBORA. Although it was found that the Church Council was performing a private function regarding chancel repairs, ${ }^{44}$ Lord Hobhouse stated that some of a minister's functions, including performing marriages and keeping the register, are public. ${ }^{45}$ This view also received some support from the Human Rights Joint Committee in its scrutiny of the recent English same-sex marriage legislation. ${ }^{46}$ While the New Zealand courts are not bound by House of Lords obiter dicta, the fact that this view was adopted in the highest United Kingdom court, examining a similar legislative provision, is particularly persuasive.

In sum, the courts are likely to hold that celebrants perform a public function when solemnising marriages. NZBORA therefore applies to celebrants' actions in the performance of this function through s 3(b), and they are thus obliged to act consistently with NZBORA. ${ }^{47}$ Unless s 29(1) can be shown to exclude obligations arising under s 3(b) of NZBORA, a celebrant remains subject to these obligations and could only refuse to conduct a marriage if to do so would be consistent with NZBORA. Section 4 of NZBORA makes it subordinate to other legislation to the extent of any inconsistency by rendering courts unable to:

(a) Hold any provision of [an] enactment to be impliedly repealed or revoked, or to be in any way invalid or ineffective; or

(b) Decline to apply any provision of [an] enactment-

by reason only that the provision is inconsistent with any provision of [the] Bill of Rights.

As a result, if the wording of s 29(1) is such that it overrides celebrants' obligations under s 3(b) of NZBORA, s 29(1) will trump these obligations. The next question is therefore a question of statutory interpretation: whether s 29(1) overrides obligations arising through NZBORA.

43 Parochial Church Council of the Parish of Aston Cantlow and Wilmcote with Billesley, Warwickshire v Wallbank [2003] 3 WLR 283 (HL) [Wallbank].

44 Wallbank, above n 43, at [63]-[64] and [88].

45 At [86] per Lord Hobhouse.

46 House of Lords and House of Commons Joint Committee on Human Rights Legislative Scrutiny: Marriage (Same Sex Couples) Bill (4 July 2013) at 20.

47 Claudia Geiringer and Steven Price "Moving from Self-Justification to Demonstrable Justification: The Bill of Rights and the Broadcasting Standards Authority" in J Finn and S Todd (eds) Law, Liberty, Legislation: Essays in Honour of John Burrows QC (LexisNexis, Wellington, 2008) 295 at 304-305. 


\section{B Does s 29(1) Exclude Obligations Arising Under NZBORA?}

The leading approach to statutory interpretation when human rights are affected is that of the Supreme Court in $R v$ Hansen (Hansen). The methodology adopted by the majority is as follows: ${ }^{48}$

(1) Ascertain the "intended" or "ordinary" meaning of the provision.

(2) Determine whether this intended meaning is apparently inconsistent with the relevant right or freedom.

(3) If so, is this apparent inconsistency a justified limit in terms of s 5 of NZBORA?

(4) If the inconsistency is a justified limit, Parliament's intended meaning prevails.

(5) If the inconsistency is not a justified limit, examine the words again under s 6 of NZBORA to ascertain whether it is reasonably possible for a meaning consistent or less inconsistent with the relevant right to be found in them. If so, adopt that meaning.

(6) If it is not reasonably possible to adopt a more consistent meaning, Parliament's intended meaning prevails due to s 4 .

To clarify, one must first ascertain the meaning of the provision using traditional principles of statutory interpretation, without reference to the interpretive direction of s 6 of NZBORA. ${ }^{49}$ Once the "intended meaning" is determined, the issue becomes whether this meaning prima facie breaches NZBORA, and if so, whether this breach can be demonstrably justified under s $5 .{ }^{50}$ Only if the meaning creates an unjustifiable breach of NZBORA can one consider whether an alternative meaning more consistent with NZBORA is reasonably open. ${ }^{51}$

\section{The intended meaning of $s$ 29(1)}

The courts' task is to interpret the text of a statute in its context, giving effect to the intentions of those who drafted it. ${ }^{52}$ This is reflected in s 5(1) of the Interpretation Act 1999 which states that "the meaning of an enactment must be ascertained from its text and in the light of its purpose".

Nothing in the legislative debates for the 1955 or 1908 Marriage Acts gives any indication of Parliament's intention in relation to s $29(1) .{ }^{53}$ Furthermore, NZBORA did not even exist when s

$48 R$ v Hansen [2007] NZSC 7, [2007] 3 NZLR 1 at [57]-[62] per Blanchard J, [88]-[92] per Tipping J and [192] per McGrath J.

49 Claudia Geiringer "The Principle of Legality and the Bill of Rights Act: A Critical Examination of $R v$ Hansen" (2008) 6 NZJPIL 59 at 68.

50 At 68-69.

51 At 69.

52 JF Burrows and RI Carter Statute Law in New Zealand (4th ed, LexisNexis, Wellington, 2009) at 319.

53 See (8 August 1908) 144 NZPD; (19 July 1955) 306 NZPD; (12 August 1955) 306 NZPD; (25 October 1955) 307 NZPD. 
29(1) was passed. However, courts generally take an "ambulatory" approach to statutory interpretation, interpreting statutes in a way that keeps them up to date with new developments, social values and changes in society. ${ }^{54}$ Acts are thus capable of "tak[ing] on a life of their own", and adapting to changing circumstances not envisaged by the legislature at the time of their passage. ${ }^{55}$ This is reflected in s 6 of the Interpretation Act, which states that enactments "appl[y] to circumstances as they arise". Therefore s 29(1) could, in today's context, be seen as overriding NZBORA obligations, even if the legislature did not foresee the provision having this effect. Indeed, rather than asking whether the legislature intended to exclude obligations arising through NZBORA, it is more useful to consider whether the wording of s 29(1) is so specific as to exclude obligations arising elsewhere in the law (including those arising through NZBORA).

It has been argued that a reading of s 29(1) that leaves celebrants subject to human rights obligations cannot be Parliament's intended meaning, as this would lead to absurd consequences. ${ }^{56}$ For example, a refusal by a Catholic priest to solemnise the marriage of two divorcees, or any refusal based on a prohibited ground of discrimination, would be unlawful. ${ }^{57}$ The argument is that a meaning leading to such absurd consequences could not possibly be intended by Parliament. ${ }^{58}$ However, this assertion was made on the basis that celebrants' actions are not public functions, and thus pt 2 of the HRA applies, rather than NZBORA. On the above analysis of s 3(b) however, this is incorrect. Unlike pt 2 of the HRA, NZBORA provides an additional layer of protection through s 5, and as such these so-called "absurd" consequences will not arise unless it is also found that the refusal was not demonstrably justifiable under s 5 . A s 5 analysis is likely to avoid any absurdity. It therefore cannot be said that s 29(1) requires NZBORA obligations to be excluded in order to prevent absurd results.

Moreover, the wording of s 29(1) is simply not specific enough to suggest that obligations arising from elsewhere in the law (namely from NZBORA) are excluded, nor does its wider context suggest this. More specific wording (for example, "notwithstanding any other provision or enactment, no celebrant shall be obliged to solemnise any marriage") would be required to clearly rule out NZBORA obligations. Finally, it may also be argued that under the "principle of legality" (a common law presumption that Parliament does not intend to legislate contrary to fundamental human rights, only rebutted by clear wording to the contrary), ${ }^{59}$ Parliament cannot be said to have

54 Burrows and Carter, above n 52, at 397.

55 At 387-390 and 401; $R$ v Hansen, above n 48, at [14] per Elias CJ.

56 Andrew Geddis "The gays are NOT coming for your churches" (2012) Pundit < www.pundit.co.nz>.

57 Geddis, above n 56.

58 Geddis, above $\mathrm{n} 56$.

59 Claudia Geiringer "Shaping the interpretation of statutes: Where are we now in the section 6 debate" in Using the Bill of Rights in Civil and Criminal Litigation (Continuing Legal Education NZLS, Wellington, 
intended to override NZBORA obligations without clear wording to this effect. However, it is unclear whether the Court in Hansen intended for "value-oriented" methods of interpretation like this to be factored in at the first stage of the Hansen methodology, especially as this may undermine the need for a later s 6 inquiry. ${ }^{60}$

Regardless of whether this presumption applies here, the text and purpose of s 29(1) do not specifically exclude obligations arising from elsewhere in the law, such as NZBORA obligations. The provision therefore only gives celebrants the power to refuse to solemnise a marriage if to do so is consistent with their obligations under s 3(b) of NZBORA. As this interpretation takes NZBORA obligations into account, it is more consistent with NZBORA rights than the alternative, and will be adopted under the Hansen approach. Nevertheless, this article will continue the Hansen analysis on the alternative basis that s 29(1) does, on its proper construction, exclude NZBORA obligations, and determine whether this meaning would be adopted by the courts. The rationale for this is two-fold. First, the above conclusion on the meaning of s 29(1) may be erroneous. Secondly, the following steps will allow valuable exploration of the rights at issue through the remaining Hansen steps.

\section{Is this meaning apparently inconsistent with s 19?}

The next question is whether Parliament's intended meaning (assuming in the alternative that $\mathrm{s}$ 29(1) does override NZBORA obligations that would otherwise apply to celebrants, and they can therefore refuse to solemnise a marriage for any reason) is apparently inconsistent with couples' rights to freedom from discrimination. Section 19(1) of NZBORA states that "[e]veryone has the right to freedom from discrimination on the grounds of discrimination in the Human Rights Act 1993." The relevant grounds of discrimination for the purposes of this discussion are sex and sexual orientation. ${ }^{61}$

The Court of Appeal has recently clarified the meaning of discrimination in Ministry of Health $v$ Atkinson (Atkinson). Prima facie discrimination is established where there is differential treatment of a person or group in comparable circumstances, based on a prohibited ground of discrimination, which imposes a material disadvantage on that person or group. ${ }^{62}$ Prima facie discrimination is therefore defined broadly, allowing the party seeking to justify it to do so under s 5 of NZBORA. A celebrant who refuses to solemnise a same-sex couple's marriage treats the couple differently from others in comparable circumstances (for example, opposite-sex couples seeking get married). Is this

2008) 1 at 12. See $R v$ Secretary of State for the Home Department, ex parte Simms [2000] 2 AC 115 (HL) at 131 per Lord Hoffmann. See also $R v$ Pora [2001] 2 NZLR 37 (CA) at [53] per Elias CJ.

60 Geiringer, above n 49, at 84-85.

61 Human Rights Act 1993, s 21(1)(m) and (a).

62 Ministry of Health $v$ Atkinson [2012] NZCA 184, [2012] 3 NZLR 456 at [109]. 
differential treatment "based on" a prohibited ground of discrimination, and does it cause a material disadvantage?

This issue involves a potential conflict between a celebrant's religious freedoms and a couple's right to be free from discrimination. Before defining discrimination, one must firstly determine whether rights are limited and balanced at the "definitional" stage (this stage), or under a s 5 analysis.

(a) Contextual or definitional balancing?

Two cases have suggested differing approaches to reconciling conflicting rights when religious freedoms are involved. In Re J (An Infant), the Court of Appeal favoured a "definitional balancing" approach, whereby both conflicting rights are read down at the definitional stage. ${ }^{63}$ Under this approach, "the scope of one right is not to be taken as so broad as to impinge upon and limit others". ${ }^{64}$ Thus, the scope of the appellants' right to freedom of religion was defined so as to exclude endangering the health of their children, and the conflicting rights were reconciled without recourse to 5.65

In contrast, the "contextual balancing" approach defines rights broadly, and leaves the balancing of conflicting rights until the s 5 stage. ${ }^{66}$ This approach has been favoured by the Supreme Court of Canada, ${ }^{67}$ and was also adopted more recently by the District Court in Police $v$ Razamjoo (Razamjoo). In Razamjoo, the rights of two witnesses to manifest their religion were limited at the $\mathrm{s}$ 5 stage in order to give effect to the defendant's conflicting right to a fair trial. ${ }^{68}$ This article asserts that the contextual balancing approach is more suitable to the rights in question. First, it has been favoured by academics. ${ }^{69}$ Secondly, it resolves conflicts of rights in the context in which they arise,

63 Re J (An Infant): B and B v Director-General of Social Welfare [1996] 2 NZLR 134 (CA) at 154.

64 At 154 .

65 At 154 .

66 Andrew Butler and James Shaerf "Limiting fundamental rights: How on earth is s 5 supposed to work in practice?" in Using the Bill of Rights in Civil and Criminal Litigation (Continuing Legal Education NZLS, Wellington, 2008) 23 at 26; Tessa Bromwich "Should God be expelled from our schools?: a human rights analysis of religion's place in New Zealand education" (LLM Dissertation, Victoria University of Wellington, 2006) at 44.

$67 B(R) \vee$ Children's Aid Society of Metropolitan Toronto [1995] 1 SCR 315 at 374.

68 Police v Razamjoo (2005) 8 HRNZ 604 (DC) at [105]-[109].

69 Rishworth and others, above n 18, at 56; Bromwich, above n 66, at 44; Andrew Butler "Limiting Rights" (2002) 33 VUWLR 537 at 542. 
allowing a clearer, more transparent balancing exercise, and avoids building limitations into the rights themselves that may be unsuitable in other contexts. ${ }^{70}$

Finally, the contextual balancing approach is more suitable to the discrimination context. Atkinson defines prima facie discrimination broadly without value judgements, balancing or questions of reasonableness, allowing such justification at the s 5 stage. ${ }^{71}$ This deference to s 5 seems inconsistent with the definitional balancing approach, and suggests that the contextual balancing approach is more appropriate. Indeed, it would seem inconsistent with Atkinson, which clearly defines prima facie discrimination, to then narrow the scope of the definition by allowing questions of justification to creep in at the definitional stage. This article will therefore proceed on the basis that the contextual balancing approach would be adopted in this situation.

(b) "Based on" a prohibited ground?

While this step may seem straightforward, one could argue that the refusal to solemnise a samesex marriage is neither based on the couple's sex, nor their sexual orientation. For example, a celebrant could refuse to marry two heterosexual people of the same sex, without discriminating based on sexual orientation. This view was taken in Quilter by Gault J. His Honour found that the registrar who refused to issue a marriage licence to the appellants (a same-sex couple) did so merely because the marriage was not valid under the Marriage Act, rather than based on the couple's sex or sexual orientation. ${ }^{72}$ However, in the author's opinion, this refusal was still based on the fact that the couple were of the same sex, as is the celebrant's refusal in the above example.

Moreover, Tipping and Thomas JJ disagreed with Gault J, holding that the prohibition of samesex marriage constitutes differentiation based on sexual orientation. ${ }^{73}$ Both focussed on the impact of the prohibition on same-sex couples as opposed to opposite-sex ones, and found that those practically affected by the prohibition were almost exclusively homosexuals. ${ }^{74}$ This impact-based approach has been preferred overseas recently, ${ }^{75}$ and is likely to be applied in New Zealand.

When looked at in terms of impact, the refusal to solemnise a same-sex marriage also differentiates based on sexual orientation (and perhaps sex). A celebrant who refuses to solemnise a

70 Butler, above n 69, at 543; Quilter v Attorney-General, above n 2, at 576 per Tipping J; Bromwich, above n 66 , at 44 .

71 Ministry of Health $v$ Atkinson, above n 73, at [109].

72 Quilter v Attorney-General, above n 2, at 526 per Gault J.

73 At 543, 569 and 601-603 per Thomas and Tipping JJ.

74 At 543, 569 and 601-603 per Thomas and Tipping JJ.

75 See for example Halpern v Canada (Attorney General) (2003) 225 DLR (4th) 529 (ONCA) at [67]-[76]. 
same-sex marriage due to religious objection to that marriage therefore treats a couple differently from others in comparable circumstances based on prohibited grounds of discrimination. ${ }^{76}$

\section{(c) Material disadvantage?}

Will a refusal to solemnise a couple's marriage cause them a material disadvantage? Even putting aside the effect of a refusal on a couple's dignity, a material disadvantage could result from a refusal in some circumstances. First, while a couple will usually have a wide choice of celebrants and registrars willing to solemnise their marriage, in some situations there may not be any willing celebrants available, such as in more isolated areas. In such a situation, refusal could lead to a couple either having to travel to a willing celebrant, or bring one to them at their own expense. A court is likely to find a material disadvantage in this situation, especially given the discussion of financial detriment as a material disadvantage in recent case law. ${ }^{77}$

The couple may also belong to a religious body, and wish to be married by their religious leader in their church. The couple may feel a strong attachment to their faith and their religious community, and the refusal to have their marriage solemnised in their church by their minister may be a serious issue for them.

Most important though is the impact of a refusal on the couple's dignity. As Thomas J affirmed in Quilter, the fundamental purpose of s 19 is to protect human dignity. ${ }^{78}$ Denying a same-sex couple the same treatment based on their sex or sexuality "inescapably judges them less worthy of respect, concern and consideration" than opposite-sex couples. ${ }^{79}$ While the dignity-centred Canadian approach to discrimination was rejected in Atkinson, ${ }^{80}$ it is likely that the effects of differential treatment on a victim's dignity will still be relevant to establishing a material disadvantage. Canadian authority therefore remains useful to this extent.

The Canadian Supreme Court has noted that "human dignity is harmed by unfair treatment premised upon personal traits or circumstances which do not relate to individual needs, capacities or merits". ${ }^{81}$ Furthermore, the Ontario Court of Appeal in Halpern $v$ Canada commented that: ${ }^{82}$

76 Human Rights Act 1993, s 21(1)(a) and (m).

77 Ministry of Health v Atkinson, above n 62, at [126]; Child Poverty Action Group Inc (CPAG) v AttorneyGeneral (2009) 19 PRNZ 689 (HC) at [128].

78 Quilter v Attorney-General, above n 2, at 536 per Thomas J.

79 At 569 per Thomas J.

80 Ministry of Health $v$ Atkinson, above n 62, at [110].

81 Law v Canada (Minister of Employment and Immigration) [1999] 1 SCR 497 at 530.

82 Halpern v Canada, above n 75, at [107]. 
[E]xclusion [from the institution of marriage] perpetuates the view that same-sex relationships are less worthy of recognition than opposite-sex ones. In doing so it offends the dignity of the persons in samesex relationships.

Refusal to solemnise the marriage of a same-sex couple sends the same message, and has the same effect on the couple's dignity. Also, in the case of a religious couple in the above example, the refusal may indicate that their union is invalid and unacceptable in the eyes of their religious community. This kind of exclusion has the effect of harming the dignity of the couple, and will constitute a material disadvantage.

In sum, despite the likelihood that willing celebrants will be available to a couple, any refusal is likely to cause a material disadvantage to a couple by excluding or stigmatising them, and thus affecting their human dignity. Practical disadvantages may also apply depending on the circumstances. Section 19 is therefore prima facie infringed.

\section{A Justified limitation?}

Section 5 of NZBORA requires that a limitation on a right is both prescribed by law and can be demonstrably justified in a free and democratic society. Section 29(1) is a legislative provision, and the limitation contained in it is prescribed by law. The question of whether it can be demonstrably justified is addressed below. The onus of proving that a limit is justified is on the party seeking to limit the right. ${ }^{83}$

(a) The Oakes test

The Court in Hansen adopted the test from $R v$ Oakes, as modified by subsequent case law, ${ }^{84}$ to determine whether s 5 is satisfied. Tipping $\mathrm{J}$ provides a summary: ${ }^{85}$

(a) does the limiting measure serve a purpose sufficiently important to justify curtailment of the right or freedom?

(b) (i) is the limiting measure rationally connected with its purpose?

(ii) does the limiting measure impair the right or freedom no more than is reasonably necessary for sufficient achievement of its purpose?

(iii) is the limit in due proportion to the importance of the objective?

$83 R v$ Hansen, above $\mathrm{n} 48$, at [108].

$84 R$ v Oakes [1986] 1 SCR 103 at 105-106; $R$ v Chaulk [1990] 3 SCR 1303 at 1341-1343; Libman v Quebec (Attorney General) [1997] 3 SCR 569 at 605.

$85 R v$ Hansen, above $\mathrm{n} 48$, at [104] per Tipping J. 
Put simply, s 5 justification "is essentially an inquiry into whether a justified end is achieved by proportionate means". 86

(b) Does the limiting measure serve a sufficiently important purpose to justify limiting s 19 ?

As the following will explain, enforcement of couples' s 19 rights (by requiring celebrants to perform marriages contrary to their religious beliefs) would come at the expense of celebrants' religious freedoms, another set of rights also protected by NZBORA and international law. ${ }^{87}$ Therefore, supposing that the intended meaning of s 29(1) excludes NZBORA obligations, it can be assumed that the purpose of the limiting measure created by s 29(1) is to protect celebrants' religious freedoms. The following will explain the competing rights, and how they are prima facie breached if s 19 is not limited.

\section{Section 13 of NZBORA states:}

Everyone has the right to freedom of thought, conscience, religion and belief, including the right to adopt and hold opinions without interference.

Section 15 states:

Every person has the right to manifest that person's religion or belief in worship, observance, practice, or teaching, either individually or in community with others, and either in public or in private.

Protection of religious freedoms is essential to ensure religions and their members maintain their religious autonomy and integrity. ${ }^{88}$ The European Court of Human Rights (ECtHR) has held that "[t]he autonomous exercise of religious freedoms ... is indispensable for pluralism in a democratic society." 89

Sections 13 and 15 are based on Article 18(1) of the International Covenant on Civil and Political Rights 1966 (ICCPR). ${ }^{90}$ This states that: ${ }^{91}$

Everyone shall have the right to freedom of thought, conscience and religion. This right shall include freedom to have or to adopt a religion or belief of his choice, and freedom, either individually or in

86 At [123] per Tipping J.

87 New Zealand Bill of Rights Act 1990, ss 13 and 15; International Covenant on Civil and Political Rights, above $n$, art 18 .

88 Ira Lupu and Robert Tuttle "Same-Sex Family Equality and Religious Freedom" (2010) 5 NWJLSP 274 at 286.

89 Supreme Holy Council of the Muslim Community v Bulgaria (39023/97) Section I, ECHR 16 December 2004 at [93].

90 Paul Rishworth "The Religion Clauses of the New Zealand Bill of Rights" [2007] NZ L Rev 631 at 641.

91 International Covenant on Civil and Political Rights, above n 6, art 18(1). 
community with others and in public or private, to manifest his religion or belief in worship, observance, practice and teaching.

Article 18(2) states that "[n]o one shall be subject to coercion which would impair his freedom to have or to adopt a religion or belief of his choice." It allows no limitation on the right to hold a religious belief. ${ }^{92} \mathrm{New}$ Zealand courts have agreed with this, describing the s 13 right as "absolute". 93

Conversely, the right to manifest one's religion or beliefs is not absolute. Article 18(3) of the ICCPR states:

Freedom to manifest one's religion or beliefs may be subject only to such limitations as are prescribed by law and are necessary to protect public safety, order, health, or morals or the fundamental rights and freedoms of others.

The corresponding right in s 15 of NZBORA has been subject to numerous limitations in New Zealand case law. ${ }^{94}$

(i) Inconsistency with s 13 ?

Section 13 is said to protect "freedom from religion", in that it prevents improper imposition of beliefs on an individual. ${ }^{95}$ While there is limited New Zealand litigation surrounding the meaning and scope of $s$ 13, a similar provision of the Canadian Charter of Rights and Freedoms was examined by the Canadian Supreme Court in $R v$ Big M Drug Mart Ltd. ${ }^{96}$ In this case the Court found that legislation prohibiting Sunday trading amounted to coercing individuals to adhere to Christian beliefs. ${ }^{97}$ The Court characterised religious freedom as "the absence of coercion and constraint", stating that the right is infringed when one is compelled to act in a way that is contrary to his or her beliefs or conscience. ${ }^{98}$ It could equally be said then that if a religiously objecting celebrant is legally required (giving effect to s 19 rights) to solemnise a same-sex marriage, he or she (like the non-Christians in $R v$ Big M Drug Mart) is being compelled to act in a way that is

92 United Nations Human Rights Committee General Comment No 2: The right to freedom of thought, conscience and religion (Art 18) 48th sess CCPR/C/21/Rev1/Add4 (1993) at [3].

93 Police v Razamjoo, above n 68, at [97].

94 See for example Feau v Department of Social Welfare (1995) 2 HRNZ 528 (HC); Re J (An Infant), above n 63; Police v Razamjoo, above n 68.

95 Rishworth and others, above n 18, at 285.

$96 \quad R v$ Big M Drug Mart Ltd (1985) 18 DLR (4th) 321 (SCC).

97 At 354 .

98 At 354 
contrary to his or her beliefs. Such a requirement could be found to coerce his or her beliefs, and thus limit his or her freedom of religion.

However, it cannot be said with certainty that $R v$ Big M Drug Mart fits the above reasoning. This decision dealt with the imposition of Christian beliefs on non-Christians, and the main rationale for the Court's finding was that the law was that it compelled people to act in a certain way for a purely religious reason. ${ }^{99}$ Thus, the state took a position on Sabbath-observance and effectively favoured Christians over non-Christians. ${ }^{100}$ This is quite different from imposing constraints based on notions of equality rather than religion, by compelling a celebrant to solemnise a same-sex marriage.

Nevertheless, both situations involve the compulsion to act contrary to one's beliefs or conscience - something which the Canadian Supreme Court emphasises is repugnant to the Charter right to freedom of religion. While it is unclear whether this broad Canadian approach to this right would be adopted in New Zealand, it is possible that our courts could find that upholding a couple's s 19 right in this context does infringe an objecting celebrant's right to freedom of religion.

(ii) Inconsistency with s 15 ?

It can be said with more certainty that upholding a couple's s 19 right would breach the celebrant's right to manifest his or her religion in practice. ${ }^{101}$ "Practice" is defined in this context as "actions taken or avoided based on religious belief". ${ }^{102}$ If a celebrant refuses to solemnise a samesex marriage because it would be contrary to his or her religious beliefs to do so, this refusal is an action taken based on those religious beliefs. This view is supported by international authority. Eweida and Others $v$ The United Kingdom dealt in part with the refusal by an applicant (a registrar) to issue a marriage licence to a same-sex couple because of a conflict with her Christian beliefs. ${ }^{103}$ While the applicant's claim was one of discrimination, the ECtHR held that her refusal was "directly motivated by her religious beliefs" and came within the ambit of art 9 of the European Convention on Human Rights (a similar provision to ss 13 and 15 of NZBORA). ${ }^{104}$ The Court also held that the refusal by another appellant to counsel same-sex couples was directly motivated by his Christian beliefs, and a manifestation of them within art $9 .{ }^{105}$ A celebrant's refusal is therefore also likely to

99 Rishworth, above n 90, at 643.

100 At 643.

101 New Zealand Bill of Rights Act 1990, s 15.

102 Rishworth and others, above n 18, at 294.

103 Eweida and Others $v$ The United Kingdom (2013) 57 EHRR 8 (Section IV, ECtHR) at [102]-[106].

104 At [103]; European Convention on Human Rights (signed 4 November 1950, entered into force 3 September 1953), art 9.

105 Eweida and Others $v$ The United Kingdom, above n 103, at [108]. 
constitute a manifestation of religious beliefs in practice, under s 15 . This right will be prima facie breached if he or she is unable to manifest his or her beliefs by refusing to solemnise a marriage on religious grounds.

(iii) Sufficiently important?

Failure to limit a couple's s 19 rights would (at least prima facie) infringe a celebrant's religious freedoms. Dickson CJ in Oakes held that an objective must "relate to concerns which are pressing and substantial in a free and democratic society" to be sufficiently important. ${ }^{106}$ According to His Honour, one core principle of a free and democratic society is "accommodation of a wide variety of beliefs". ${ }^{107}$ Protection of religious freedoms (another set of fundamental rights) is therefore a sufficiently important purpose to justify limiting s 19.

(c) Rational connection?

The limiting provision must be rationally connected its object. ${ }^{108}$ An interpretation of s 29(1) excluding NZBORA obligations allows celebrants to refuse on any grounds. This protects their ability to refuse due to objection on religious grounds, and thus safeguards their religious freedoms. Assuming that the purpose of s 29(1) is to protect celebrants' religious freedoms, the limiting measure is rationally connected with this purpose.

(d) Does the limiting measure impair the right no more than reasonably necessary?

Although perhaps intended to protect religious freedoms, s 29(1) read in this way allows refusal on any grounds, not just religious ones. Under this broad exemption, a celebrant could refuse to solemnise a marriage because, for example, the couple was Asian. Prejudicial and discriminatory refusals not based on legitimate religious belief would be allowed under this interpretation, enabling a far greater incursion on the s 19 right than is reasonably necessary to achieve the objective.

(e) Is the limit proportionate to the importance of the objective?

This step is an "overall broad-brush question as to whether the limit is justified on the basis of how it is effected". ${ }^{109}$ It requires that there is: ${ }^{110}$

proportionality between the effects of the limiting measure and its objective, so that the more severe the

deleterious effects of the measure, the more important must be the objective it seeks to attain.

$106 R v$ Oakes, above n 84, at 138-139.

107 At 136.

$108 R v$ Hansen, above $\mathrm{n} 48$, at [212] per McGrath J.

109 Butler and Shaerf, above n 77, at 35.

$110 R v$ Hansen, above $\mathrm{n} 48$, at [204] per McGrath J. 
It must therefore be established that the limitation on s 19 is a "proportionate response" given the importance of protecting celebrants' religious freedoms. ${ }^{111}$ It will be established that compelling celebrants to solemnise marriages contrary to their religious beliefs would place an unjustifiable and disproportionate burden on them, and couples' rights under s 19 should therefore be limited to enable celebrants to refuse on religious grounds. However, allowing them to refuse for any reason limits s 19 unnecessarily and is not a proportionate response.

It has been argued that adherence to religious beliefs and doctrine is as fundamental a part of the identities of religious objectors, as a sexual orientation is a part of the identities of homosexuals. ${ }^{112}$ Both of these aspects of identity are central to a person's character, and should not be subject to unnecessary state interference or coercion. ${ }^{113}$ Coercing someone with strong religious beliefs to act contrary to those beliefs or preventing them from manifesting them, is oppressing a fundamental part of their identity in a similar way to preventing a homosexual from living according to his or her sexual orientation. Both parties' identities must be protected by a compromise if this is possible.

The Canadian Supreme Court has considered this issue. It held in Reference re Same-Sex Marriage that "absent exceptional circumstances", state compulsion of religious officials to perform same-sex marriages contrary to their religious beliefs would unjustifiably limit the right to freedom of religion in s 2(a) of the Canadian Charter. ${ }^{114}$ It noted that the protection granted to religious freedoms under s 2 of the Charter are broad, ${ }^{115}$ and clarified that this ruling applies to both civil and religious same-sex marriages. ${ }^{116}$ Charter case law has held that s 2(a) encompasses: ${ }^{117}$

... the right to believe and entertain the religious beliefs of one's choice, the right to declare one's religious beliefs openly and the right to manifest religious belief by ... religious practice.

The NZBORA is modelled on the Charter, and this meaning is almost identical to ss 13 and 15. Like Canada, New Zealand has no established religion and both countries are relatively secular. It is therefore likely that the protection granted to religious freedoms under ss 15 and 13 in the New Zealand context is similarly broad. Thus, upholding a couple's s 19 rights and

111 At [211] per McGrath J.

112 Thomas C Berg "What Same-Sex Marriage and Religious Liberty Claims Have in Common" (2010) 5 NWJLSP 206 at 212.

113 At 207 and 212.

114 Constitution Act RSC 1982, sch B: Canadian Charter of Rights and Freedoms, s 2(a); Reference re SameSex Marriage [2004] 3 SCR 698 at [58].

115 At [55].

116 At [60].

117 At [57]; $R v$ Big M Drug Mart Ltd, above n 96, at 336-337. 
compelling a religiously objecting celebrant to solemnise a marriage would likely create an unacceptable limitation to the celebrant's rights under s 15.

The practical implications of not limiting the right must also be considered. A same-sex couple will likely be offended by a refusal to solemnise their marriage. Such an impact on their dignity and sense of self-worth is no trivial matter. Furthermore they may be inconvenienced and financially disadvantaged. However, usually both market forces and relatively widespread acceptance of samesex marriage will make finding an alternative a simple matter of looking to the next entry in the phone book. ${ }^{118}$

Conversely if the right is not limited, an objecting celebrant could face legal sanction. A celebrant found liable for discrimination and obliged to perform a same-sex marriage must either violate the tenets of his or her faith or cease being a celebrant. ${ }^{119}$ To deeply religious celebrants, disobeying their religious beliefs is no trivial matter, and may have serious and eternal repercussions. ${ }^{120}$ This may leave a celebrant in a position where he or she can perceive no other choice but to resign. Although being a celebrant is not generally a full-time profession, performing marriages may be a central function of many churches and approved organisations (most of which are religiously oriented). ${ }^{121}$ Furthermore in the case of both independent celebrants and others, being a celebrant may be a deeply fulfilling and important role, as well as a source of income.

The Ministry of Justice has argued that allowing independent celebrants to refuse to conduct marriages on religious grounds is not justifiable as they are not appointed to promote their religious beliefs, and their role is akin to that of a registrar. ${ }^{122}$ However, s 11 of the Marriage Act allows independent celebrants to be appointed based on their religious beliefs. ${ }^{123}$ Moreover, unlike registrars, they are not public servants. While (like all celebrants) their statutory function is similar to that of a registrar, their role is not the same. Thus, while refusal by a celebrant may be both an inconvenience and hurtful to a couple, this is relatively insignificant compared with the burden imposed upon celebrants, including independent celebrants, if the s 19 right is not limited.

118 Berg, above n 112, at 229.

119 At 229

120 John H Garvey "An Anti-Liberal Argument for Religious Freedom" (1996) 7 J Contemp Legal Issues 275 at 287.

121 See "List of Churches and Approved Organisations" Department of Internal Affairs <www.dia.govt.nz>.

122 Ministry of Justice Departmental Report for the Government Administration Committee: Marriage (Definition of Marriage) Amendment Bill (2013) at 8.

123 Marriage Act 1955, s 11(3)(c) (see also above at Part II - The Statutory Scheme); Bassett Opinion, above n 39 , at 4 . 
It flows from this that it is a reasonable compromise and a justifiable limit on s 19 to allow celebrants to refuse to solemnise marriages based on their legitimate religious beliefs. If this was the extent of the limitation on s 19 created by s 29(1), it would be a justifiable one. However it is not: as mentioned above, if s 29(1) operates to exclude obligations arising through NZBORA, celebrants will be able to refuse for any reason (regardless of whether the reason can be justified). This limits $\mathrm{s}$ 19 far more than is reasonable, allowing refusal based on race and other such undesirable grounds, and goes far beyond the kind of discrimination that can be justified in a free and democratic society.

\section{(f) Conclusion}

While s 29(1) (interpreted in such a way that it excludes human rights obligations) achieves a justified end, it does not do so by proportionate means. The limitation is over-inclusive and does not distinguish between refusal based on legitimate religious beliefs and other refusals based on prejudicial grounds, and is therefore unjustifiable under s 5. Conversely, a meaning of s 29(1) that does not exclude NZBORA obligations would mean that a celebrant may only refuse to solemnise a marriage if to do so is consistent with NZBORA. It would therefore only allow justifiable limitations on $\mathrm{s} 19$ (for example those protecting celebrants' religious freedoms) and not others. This interpretation is more consistent with NZBORA. Can it, then, be adopted under s 6 ?

\section{Is a meaning more consistent with NZBORA available?}

As the limit is unjustifiable, the court will analyse whether an alternative meaning consistent (or less inconsistent) with the rights enshrined in NZBORA is available on the wording of s 29(1). ${ }^{124}$ If not, s 4 requires that the intended meaning is adopted. ${ }^{125}$ In Hansen, the Supreme Court reached a majority consensus on three rules regarding the limits of permissible interpretation under s $6 .{ }^{126}$ First, interpretations must be "reasonably possible" or "tenable". ${ }^{127}$ Secondly, in order to be tenable, a meaning must be genuinely open on the text of the statute. ${ }^{128}$ Finally, the meaning must not be inconsistent with statutory purpose. ${ }^{129}$ In other words, courts' interpretative mandate under s 6 must not be used as a "concealed legislative tool" to subvert Parliament's intended meaning. ${ }^{130}$

$124 R v$ Hansen, above $\mathrm{n} 48$, at [92] per Tipping $\mathrm{J}$.

125 At [167] per Tipping J.

126 Geiringer, above n 49, at 73.

127 At 73; $R \vee$ Hansen, above $\mathrm{n}$ 48, at [25], [157]-[158] and [288]-[290] per Elias CJ and Tipping and Anderson JJ.

128 Geiringer, above n 49, at 73; $R$ v Hansen, above n 48, at [25], [61] and [237] per Elias CJ and Blanchard and McGrath JJ.

129 Geiringer, above $n$ 49, at 73; $R v$ Hansen, above $n$ 48, at [25], [61], [156]-[158] and [248]-[252] per Elias $\mathrm{CJ}$ and Blanchard, Tipping and McGrath JJ.

130 At [156] per Tipping J. 
As mentioned above, an interpretation more consistent with NZBORA is that s 29(1) does not oust obligations arising from NZBORA. Is this reasonably possible in light of its text and purpose? Here, assuming (in the alternative) that the intended meaning of $s$ 29(1) overrides obligations from NZBORA, this interpretation is directly at odds with the statutory purpose. It is therefore likely to be impermissible under the view of the Court in Hansen that "section 6-mandated interpretation must always operate within the constraints set by statutory purpose". 131

This effectively means this final step of the Hansen analysis is defeated by the intended meaning established at step one. However it has been argued that courts may, "at the extremes", adopt meanings that are contrary to the statutory purpose. ${ }^{132}$ In Zaoui $v$ Attorney-General (No 2) (Zaoui), ${ }^{133}$ the Supreme Court showed an apparent willingness to do this. The Court used s 6 and the presumption of consistency with international law to read down the powers of deportation conferred by s 72 of the Immigration Act 1987, requiring that they are exercised consistently with ss 8 and 9 of NZBORA. ${ }^{134}$ This was despite "a number of strong indications within the scheme of the Immigration Act" that once a security risk certificate is issued, the individual concerned is to be deported. ${ }^{135}$ It is therefore possible in light of Zaoui that a court might be willing to depart from statutory purpose here.

However, it is unclear whether the courts are likely to take this approach, especially given the clear expression by the Supreme Court two years later in Hansen that the $\mathrm{s} 6$ interpretive power is constrained by statutory text and purpose. As the law stands from Hansen, a departure from the statutory purpose of s 29(1) is unlikely. Moreover, even if the courts are willing to adopt meanings contrary to statutory purpose in the future, it is also unclear whether this is the kind of "extreme" case where they would be willing to do so. After all, in Zaoui it was the appellant's right to life at issue. It follows that this interpretation would not be tenable.

\section{Outcome}

The intended meaning of s 29(1) does not override obligations arising through s 3(b) of NZBORA. Section 29(1) therefore only gives celebrants the power to refuse to solemnise a marriage if NZBORA allows such a refusal.

In the alternative, if s 29(1) on its intended meaning did oust NZBORA obligations, this would allow a celebrant to refuse for any reason (whether due to religious or moral beliefs or otherwise),

131 Geiringer, above n 49, at 88 .

132 At 90.

133 Zaoui v Attorney-General (No 2) [2005] 1 NZLR 577 (SC).

134 At [91]; Geiringer, above n 49, at 91.

135 At 91 . 
which would infringe same-sex couples' s 19 rights in a way that is unjustifiable under s 5 . An alternative meaning more consistent with NZBORA (that s 29(1) does not oust NZBORA obligations) would be unlikely to be adopted under s 6, and Parliament's intended meaning would be preferred pursuant to s 4 . $^{136}$

\section{If NZBORA Obligations Are Not Excluded by s 29(1), Can a Celebrant Lawfully Refuse to Solemnise a Same-Sex Marriage on Religious Grounds?}

This article has established that s 29(1) does not enable a celebrant to refuse to solemnise a marriage if this would contravene his or her obligations under NZBORA. Therefore what must be established to determine whether a celebrant could lawfully refuse to solemnise a same-sex marriage on religious grounds, is whether NZBORA allows such a refusal.

It has been shown above that a refusal to solemnise a same-sex marriage based on the sex and/or sexual orientation of the couple would constitute a prima facie breach of their s 19 right to freedom from discrimination. It is also clear from the above analysis that while allowing celebrants to refuse for any reason would unjustifiably breach s 19, allowing them to refuse based on religious objection to the marriage constitutes a justified limitation on s 19 and is lawful. Therefore, although s 29(1) does not oust obligations arising from NZBORA, it still allows a celebrant to refuse to solemnise a marriage on religious grounds, because such a refusal is permitted by NZBORA.

\section{CONCLUSION}

This article has attempted to both examine the conflicting rights at issue, and explore the practical implications of s 29(1) for celebrants. In sum, on its proper construction, s 29(1) does not exclude human rights obligations arising from NZBORA. The provision therefore only allows a celebrant to refuse to solemnise a marriage if that refusal is consistent with NZBORA. A refusal based on legitimate religious beliefs is consistent with NZBORA, and s 29(1) therefore allows celebrants to refuse to solemnise same-sex marriages on religious grounds. As it would be demonstrably justifiable for all celebrants to refuse based on their own religious beliefs, s 29(1) provides a broader exemption than s 29(2). The fact that some celebrants do not fall within s 29(2) is therefore no barrier to their ability to object on religious grounds. However, s 29(2) is of course useful to the extent that it provides clarity to organisational celebrants and ministers.

$136 R v$ Hansen, above $\mathrm{n} 48$, at [92] per Tipping J. 